\title{
RESEARCH ARTICLE Optimization of Spacing and Fertilizer Requirement for Pre-release Cotton Varieties Under Irrigated Condition
}

\section{Veeraputhiran $R^{*}$}

Cotton Research Station, Tamil Nadu Agricultural University, Srivilliputtur - 626135.

Received : $17^{\text {th }}$ November, 2019

Revised : $21^{\text {st }}$ January, 2020

Revised : $13^{\text {th }}$ February, 2020

Accepted : $15^{\text {th }}$ February, 2020

\begin{abstract}
Field experiments were carried out at Cotton Research Station, Srivilliputtur from August to January 2017-18 and 2018 -19 to optimize fertilizer requirement of prerelease varieties of cotton with two levels of spacing under irrigated conditions. The experiments were conducted in a splitsplit-plot design with three replications. The treatments consisted of two pre-release cotton varieties (GSHV 177 and CCH 14-1 during 2017-18 and BGDS 1033 and CCH 15-1 during 2018-19) in main plots and two levels of plant geometry $(75 \times 30 \mathrm{~cm}$ and $75 \times 45 \mathrm{~cm})$ in subplots and three doses of fertilizers (75 \% RDF - 60:30:30 Kg NPK/ha, $100 \%$ RDF - 80:40:40 Kg NPK / ha and 125\% RDF- 100:50:50 Kg NPK/ha) were accommodated in subsubplots. The results revealed that the genotypes GSHV 177 and $\mathrm{CCH}$ 15-1 performed better by producing taller plants, a higher number of sympodia, bolls per plant, and a number of bolls $/ \mathrm{m}^{2}$ with higher seed cotton yield and economic benefits. Adoption of normally recommended spacing of $75 \times 30$ $\mathrm{cm}$ recorded significantly more bolls production and higher seed cotton yield than the wider spacing of $75 \times 45 \mathrm{~cm}$ during both the years of study. The effect of both 125 and 100 per cent RDF on a number of bolls / $\mathrm{m}^{2}$ was on par. Application of 125 per cent RDF registered comparable seed cotton yield during 2017-18 and significantly higher than 100 per cent RDF during 2018-19. Higher total income, net income and benefit-cost ratio were also observed with under $75 \times 30 \mathrm{~cm}$ spacing and 125 per cent RDF.
\end{abstract}

Keywords: Cotton varieties, economics, fertilizers, seed cotton yield, spacing.

\section{INTRODUCTION}

Cotton, also known as "white gold," is an important fibre cum cash crop in India and Tamil Nadu as well. In Tamil Nadu, cotton is cultivated in an area of 1.42 lakh ha during 2015-16 with a production of 2.80 lakh bales and productivity of $599 \mathrm{~kg} / \mathrm{ha}$ which is below the world average yield of $788 \mathrm{~kg} /$ ha (AICCIP, 2017). Fertilizer is one of the major input in cotton production. The response of cotton to applied nutrients, is governed by environment and cultural factors. Among various production factors, spacing and fertilization play a very significant role in efficient utilization of available sources. The cotton plant being a heavy feeder, needs proper fertilizer application. Balanced fertilization is one of the major key factors for sustaining and enhancing the cotton yields. Balanced fertilizer application is not only to maintain soil fertility but also for the proper functioning of plant mechanisms such as photosynthesis, metabolism, growth, and yield formation. Determination of optimum plant spacing with fertilizer dose for realizing optimum yield is necessary for maximum utilization of various resources like light, soil moisture and *Corresponding author's e-mail: veeraagri@yahoo.co.in
$\mathrm{CO}_{2}$ to augment crop yield. The effect of nutrients may differ with spacing because of their profound impact on canopy structure, phrenological behavior, and fruiting pattern. Efficient cotton production packages from the modern agronomy of cotton with optimum spacing and fertilizer application explore the avenues for realizing the potential yields. With these background, the present studies were, undertaken to optimize the spacing and fertilizer requirement of promising prerelease cotton varieties.

\section{MATERIAL AND METHODS}

Field experiments were carried out at Cotton Research Station, Srivilliputtur from August to January 2017-18 and 2018-19 to optimize fertilizer requirement of pre-release varieties of cotton with two levels of spacing under irrigated conditions. The experiments were conducted in a split- splitplot design with three replications. The treatments consisted of two pre-release cotton varieties (GSHV 177 and CCH 14-1 during 2017-18 and BGDS 1033 and $\mathrm{CCH} 15-1$ during 2018-19) in main plots, and two levels of plant geometry $(75 \times 30 \mathrm{~cm}$ and 75

$$
107|1-3| 21
$$


$x 45 \mathrm{~cm}$ ) in subplots and three doses of fertilizers (75 \% RDF - 60:30:30 Kg NPK/ha, $100 \%$ RDF 80:40:40 Kg NPK/ha, 125\% RDF- 100:50:50 Kg NPK/ha ) were accommodated in sub-subplots. The soil of the experimental field was sandy clay loam with a $\mathrm{pH}$ of 8.3. The available nutrient $\mathrm{N}, \mathrm{P}$ and $\mathrm{K}$ status of the soil was low (196 Kg/ha), high(40 $\mathrm{Kg} / \mathrm{ha}$ ), and high (440 Kg/ha), respectively. Onethird dose of nitrogen and potash and a full dose of phosphorus was applied as a basal application at the time of sowing. Top dressing of remaining dose of nitrogen and potash was given as each one-third dose at $20-25$ and $40-45$ days after sowing. The sources of nutrients were urea $(46 \% N)$, Single Superphosphate $\left(46 \% \mathrm{P}_{2} \mathrm{O}_{5}\right)$ and Muriate of potash
(60\% $\left.\mathrm{K}_{2} \mathrm{O}\right)$. All other recommended agronomic practices were followed uniformly. The biometric observation on plant height, yield attributes, and seed cotton yield were recorded, and economics were also worked out.

\section{RESULTS AND DISCUSSION}

\section{Growth characters}

The height of cotton genotypes at harvest during both the years of study and monopodia during 201819 was not significantly influenced by genotypes, spacing, and fertilizer levels. However, a significant variation in monopodia production was effected by genotypes only during 2017-18 (Table 1).

Table1. Effect of pre release varieties, spacing and fertilizer levels on growth and yield attributes of cotton

\begin{tabular}{|c|c|c|c|c|c|c|c|c|c|c|}
\hline \multirow{2}{*}{ Treatments } & \multicolumn{2}{|c|}{$\begin{array}{l}\text { Plant height at } \\
\text { Harvest }(\mathrm{cm})\end{array}$} & \multicolumn{2}{|c|}{$\begin{array}{l}\text { Monopodia } \\
\text { (No./plant) }\end{array}$} & \multicolumn{2}{|c|}{$\begin{array}{l}\text { Sympodia } \\
\text { (No./plant) }\end{array}$} & \multicolumn{2}{|c|}{$\begin{array}{c}\text { Bolls } \\
\left(\text { No. } / \mathrm{m}^{2}\right)\end{array}$} & \multicolumn{2}{|c|}{$\begin{array}{l}\text { Boll weight } \\
\text { (g) }\end{array}$} \\
\hline & 2017-18 & 2018-19 & 2017-18 & 2018-19 & $2017-18$ & 2018-19 & 2017-18 & 2018-19 & 2017-18 & 2018-19 \\
\hline \multicolumn{11}{|l|}{ Pre release varieties } \\
\hline $\begin{array}{l}V_{1} \text { (GSHV } 177 \text { during 2017-18 } \\
\& \text { CCH } 14-1 \text { during } 2018-19 \text { ) }\end{array}$ & 111.0 & 103.1 & 2.08 & 1.31 & 14.89 & 15.14 & 82.55 & 80.76 & 4.65 & 4.66 \\
\hline $\begin{array}{l}V_{2} \text { (BGDS } 1033 \text { during 2017-18 } \\
\& \text { CCH 15-1 during 2018-19) }\end{array}$ & 100.9 & 105.3 & 0.95 & 1.43 & 15.45 & 15.57 & 71.82 & 87.41 & 4.78 & 4.73 \\
\hline SE.d & 4.42 & 4.19 & 0.29 & 0.27 & 0.27 & 0.24 & 2.58 & 2.21 & 0.07 & 0.80 \\
\hline$C D(P=0.05)$ & NS & NS & 0.80 & NS & 0.76 & NS & 7.17 & 6.01 & NS & NS \\
\hline \multicolumn{11}{|l|}{ Spacing } \\
\hline Normal spacing $(75 \times 30 \mathrm{~cm})$ & 104.4 & 102.5 & 1.347 & 1.36 & 16.11 & 14.85 & 88.77 & 93.95 & 4.61 & 4.60 \\
\hline Wider spacing $(75 \times 45 \mathrm{~cm})$ & 102.4 & 101.4 & 1.444 & 1.48 & 15.65 & 15.02 & 61.53 & 71.20 & 4.65 & 4.77 \\
\hline SE.d & 4.27 & 4.05 & 0.18 & 0.17 & 0.21 & 0.20 & 2.17 & 2.94 & 0.13 & 0.11 \\
\hline$C D(P=0.05)$ & NS & NS & NS & NS & 0.52 & NS & 5.33 & 5.88 & NS & NS \\
\hline \multicolumn{11}{|l|}{ Fertilizer levels } \\
\hline $\begin{array}{l}75 \% \text { RDF } \\
(60: 30: 30 \mathrm{Kg} \mathrm{NPK} \mathrm{/} \mathrm{ha)}\end{array}$ & 100.2 & 98.6 & 1.245 & 1.22 & 15.30 & 14.44 & 71.60 & 75.97 & 4.47 & 4.38 \\
\hline $\begin{array}{l}100 \% \text { RDF } \\
(80: 40: 40 \mathrm{Kg} \mathrm{NPK} / \mathrm{ha})\end{array}$ & 103.7 & 102.2 & 1.431 & 1.34 & 15.94 & 15.26 & 76.85 & 85.08 & 4.80 & 4.58 \\
\hline $\begin{array}{l}125 \% \text { RDF } \\
\text { (100:50:50 Kg NPK/ ha) }\end{array}$ & 106.4 & 106.8 & 1.511 & 1.43 & 16.40 & 15.39 & 77.04 & 91.22 & 5.06 & 4.71 \\
\hline SE.d & 4.71 & 4.56 & 0.34 & 0.20 & 0.44 & 0.49 & 2.49 & 2.48 & 0.18 & 0.14 \\
\hline$C D(P=0.05)$ & NS & NS & NS & NS & NS & NS & 5.14 & 5.28 & NS & NS \\
\hline Interaction & NS & NS & NS & NS & NS & NS & NS & NS & NS & NS \\
\hline
\end{tabular}

Among the genotypes, $\mathrm{CCH}$ 14-1 produced significantly taller plants than GSHV 177. The results were in accordance with Singh et al. (2012), who observed the variation in plant height and monopodia by different cotton genotypes.

\section{Yield attributes}

Different genotypes, geometry, and levels of fertilizer exhibited significant influence on the number of sympodia during 2017-18 and the number of bolls per square meter during both the years of study (Table 1). Among the genotypes, GSHV 177 and $\mathrm{CCH} 15-1$ produced the highest number of bolls per square meter than $\mathrm{CCH} 14-1$ and BGDS 1033 respectively. Adoption of normal spacing of 75 x $30 \mathrm{~cm}$ produced significantly higher boll number per square meter than the wider spacing of $75 \times 45$ $\mathrm{cm}$ in both the years of experimentation. Though

the nutrient levels did not significantly influence the sympodia production, application of $125 \%$ RDF produced a significantly higher number of bolls than $100 \%$ RDF and both were significantly higher than the lesser dose of $75 \%$ RDF. However, genotypes, geometry, and levels of fertilizer did not show any significant effect on boll weight. Production of higher yield attributes under higher fertilizer dose may be because nitrogen helps in cell division and cell elongation, leading to an increased number of lateral branches. Kumar et al. (2011); and Sandeep Rawal et al. (2015), reported similar results of higher yield attributes with higher doses of fertilizers.

\section{Seed cotton yield}

The results revealed that the prerelease cotton varieties, spacing, and fertilizer levels exerted a significant effect on seed cotton yield (Table 2). 
Table 2. Effect of pre release varieties, spacing and fertilizer levels on yield and economics of cotton

\begin{tabular}{|c|c|c|c|c|c|c|c|c|c|c|}
\hline \multirow[t]{2}{*}{ Treatments } & \multicolumn{2}{|c|}{$\begin{array}{l}\text { Seed cotton yield } \\
(\mathrm{kg} / \mathrm{ha})\end{array}$} & \multicolumn{2}{|c|}{$\begin{array}{l}\text { Cost of cultivation } \\
\text { (Rs/ ha) }\end{array}$} & \multicolumn{2}{|c|}{$\begin{array}{c}\text { Total Income } \\
\text { (Rs/ ha) }\end{array}$} & \multicolumn{2}{|c|}{$\begin{array}{l}\text { Net Income } \\
\text { (Rs/ ha) }\end{array}$} & \multicolumn{2}{|c|}{ B-C Ratio } \\
\hline & $2017-18$ & 2018-19 & $2017-18$ & 2018-19 & 2017-18 & 2018-19 & $2017-18$ & 2018-19 & 2017-18 & 2018-19 \\
\hline \multicolumn{11}{|l|}{ Pre release varieties } \\
\hline $\begin{array}{l}\mathrm{V}_{1} \text { (GSHV } 177 \text { during } \\
2017-18 \& \mathrm{CCH} 14-1 \\
\text { during } 2018 \text {-19) }\end{array}$ & 2015 & 1930 & 50800 & 52900 & 92690 & 94570 & 41890 & 41670 & 1.82 & 1.79 \\
\hline $\begin{array}{l}\mathrm{V}_{2} \text { (BGDS } 1033 \text { during } \\
2017-18 \& \mathrm{CCH} 15-1 \\
\text { during } 2018-19)\end{array}$ & 1745 & 2073 & 50800 & 52900 & 80270 & 101577 & 29470 & 48677 & 1.58 & 1.92 \\
\hline SE.d & 70.1 & 73.2 & - & - & - & - & - & - & - & - \\
\hline$C D(P=0.05)$ & 194.2 & NS & - & - & - & - & - & - & - & - \\
\hline \multicolumn{11}{|l|}{ Spacing } \\
\hline $\begin{array}{l}\text { Normal spacing } \\
(75 \times 30 \mathrm{~cm})\end{array}$ & 2002 & 2098 & 50800 & 52900 & 92092 & 102802 & 41292 & 49902 & 1.81 & 1.94 \\
\hline $\begin{array}{l}\text { Wider spacing } \\
(75 \times 45 \mathrm{~cm})\end{array}$ & 1819 & 1905 & 50100 & 52200 & 83674 & 93345 & 33574 & 41145 & 1.67 & 1.79 \\
\hline SE.d & 57.7 & 70.1 & - & - & - & - & - & - & - & - \\
\hline $\mathrm{CD}(\mathrm{P}=0.05)$ & 141.2 & 141.2 & - & - & - & - & - & - & - & - \\
\hline \multicolumn{11}{|l|}{ Fertilizer levels } \\
\hline $\begin{array}{l}75 \text { \% RDF } \\
\text { (60:30:30 Kg NPK / ha) }\end{array}$ & 1807 & 1718 & 50000 & 52100 & 83122 & 84182 & 33122 & 32082 & 1.66 & 1.62 \\
\hline $\begin{array}{l}100 \% \text { RDF } \\
(80: 40: 40 \mathrm{Kg} \mathrm{NPK} / \mathrm{ha})\end{array}$ & 1921 & 2021 & 50800 & 52900 & 88366 & 99029 & 37566 & 46129 & 1.74 & 1.87 \\
\hline $\begin{array}{l}125 \text { \% RDF } \\
\text { (100:50:50 Kg NPK/ ha) }\end{array}$ & 2001 & 2266 & 51600 & 53600 & 92046 & 111034 & 40446 & 57434 & 1.78 & 2.07 \\
\hline SE.d & 68.3 & 52.0 & - & - & - & - & - & - & - & - \\
\hline$C D(P=0.05)$ & 140.1 & 110.7 & - & - & - & - & - & - & - & - \\
\hline Interaction & NS & NS & & & & & & & & \\
\hline
\end{tabular}

Among the genotypes, GSHV 177 produced the higher seed cotton yield $(2015 \mathrm{~kg} / \mathrm{ha}$ ) than $\mathrm{CCH} 14-1$ (1745 kg/ha) during 2017-18, but different varieties failed to produce significant variation during 201819. Singh et al.(2012) observed a significant difference among the cotton cultivars on seed cotton yield.

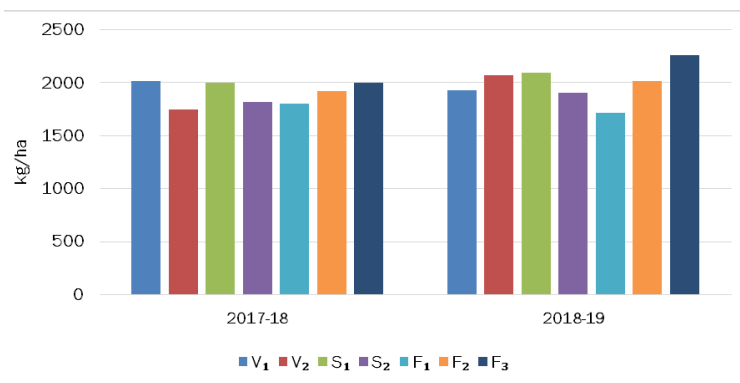

Figure 1. Effect of prerelease varieties, spacing and fertilizer levels on seed cotton yield

Concerning spacing, normal spacing significantly improved the seed cotton yield than wider spacing. During both the year of experimentation, the closer spacing of $75 \times 30 \mathrm{~cm}$ produced higher seed cotton yield (2002 and $2098 \mathrm{~kg} / \mathrm{ha}$ ) than wider spacing of $75 \times 45 \mathrm{~cm}$ (1819 and $1905 \mathrm{~kg} / \mathrm{ha}$ during 2017 18 and 2018-9 respectively). A similar result of higher seed cotton yield with closer spacing was also reported by Shukla et al.(2013) and Divya et al. (2016). The higher seed cotton yield with closer spacing was due to higher yield attributes, and a higher plant population accommodated per unit area. Manjunatha et al. (2010) reported that increasing the plant density/unit land area increased the interplant competition within the plot for natural resources and because of higher competition between plants, the contribution of yield components/plant with closer spacing was lower when compared to wider spacing, but the loss in yield attributes/plant was compensated through higher plant population/ha.

Among the fertilizer doses, application of 125 per cent RDF registered seed cotton yield of 2001 and $2266 \mathrm{~kg} / \mathrm{ha}$, during 2017-18 and 2018-19 respectively which were on par during 2017-18 and significantly higher than 100 per cent RDF during 2018-19 and both were significantly higher than 75 per cent RDF during both the years of study. Similar results of the significant increase in seed cotton yield with the application of higher fertilizer levels over RDF as reported by Ghongane et al. (2009), Venugopalan et al.(2009) and Pandagale et al. (2015) were in conformity with the present investigation. Significantly higher yield under higher fertilizer doses was due to the corresponding increase in bolls/plant and boll weight. The interaction effect was not significant.

\section{Economics}

The economic analysis clearly showed that the genotypes GSHV 177 and CCH 15-1 registered higher total income, net income, and Benefit-Cost ratio (BC / ratio) than BGDS 1033 and CCH 14-1. Regarding geometry, the normal spacing of $75 \times 30$ 
$\mathrm{cm}$ recorded higher net returns and $\mathrm{BC}$ ratio than the wider spacing of $75 \times 45 \mathrm{~cm}$ during both the years of study. Among the fertilizer levels, 125 per cent RDF resulted in higher economic returns than other doses of fertilizers during both the years of experimentation. Association of higher economic returns with a higher plant population with closer spacing was noticed by Asewar et al. (2013) and Divya et al. (2016). Similar findings of higher economic benefits with higher dose of fertilizer in cotton was observed by Bharathi et al. (2016)

\section{CONCLUSION}

Thus it is concluded from the study that normal recommended spacing of $75 \times 30 \mathrm{~cm}$ with 125 per cent recommended dose of fertilizers was optimum for prerelease varieties of cotton under irrigated conditions for higher yield and economic benefits.

\section{REFERENCES}

Anonymous, 2017. ICAR- AICCIP Annual Report, Central Institute of Cotton Research, Coimbatore.

Asewar, B.V., Pawar, S.U., Bhosle, G.P. and Gokhale, D.N. 2013. Effect of spacing and fertilizer levels on seed cotton yield and economics of Bt cotton. J. Cotton Res Dev. 27(1): 89 -94.

Bharathi S., Ratna Kumari, S., Vamsi Krishna A.N. and Chenga Reddy. V. 2016. Effect of nitrogen levels, split application of nitrogen on yield and fibre quality of $B t$ cotton in Vertisols J. Cotton Res. Dev. 30(2): 201-204

Divya, S., Saravanan, P., Kathiravan, J. and Venkatesan, P. 2016. Effect of plant spacing on yield and economics of extra-long staple (ELS) Bt cotton hybrid J. Cotton Res. Dev. 30(2): 214-217
Ghongane, S.B., Yeledhalli, N.A., Ravi, M.V., Patil, B. V., Desai, B.K. and Beledhadi, R.V. 2009. Effect of fertilizer and irrigation levels on growth, yield and quality of transgenic Bt cotton in deep Vertisols. Karnataka J. Agric. Sci. 22: 905-08.

Kumar, M., Pannu, R.K., Nehra, D.S. and Dhaka, A.K. 2011. Effect of spacing and fertilizer on growth, yield and quality of different cotton genotypes. J. Cotton Res Dev. 25: 236-39.

Manjunatha, M.J., Halepyati, A.S., Koppalkar, B. G. and Pujari, B.T. 2010. Yield and yield components, uptake of nutrients, quality parameters and economics of Bt cotton (Gossypium hirsutum L.) genotypes as influenced by different plant densities. Karnataka J.Agri. Sci. 23: 423-25.

Pandagale, A.D., Khargkharate, V.K., Kadam, G.L. and Rathod, S.S. 2015. Response of Bt cotton (Gossypium hirsutum L.) to varied plant geometry and fertilizer levels under rainfed condition. J. Cotton Res. Dev. 29(2): 260-263

Sandeep Rawal, Mehta, A.K., Thakral, S.K. and Mahesh Kumar 2015. Effect of nitrogen and phosphorus levels on growth, yield attributes and yield of $B t$ cotton J. Cotton Res. Dev. 29(1): 76-78

Singh, J., Shilpa Babar, Abraham, S,. Venugopalan, M.V.and Majumdhar, G.2012. Fertilization of highdensity rainfed cotton grown on Vertisols of India. Better crops. 96(2): 26-28.

Shukla, U.N., Khakare, M.S., Bhale, V. M. and Singh, S. 2013. Plant population, nutrient uptake and yield of cotton (Gossypium hirsutum) hybrids as affected by spacing and fertility levels under rainfed condition. Indian J. Agri.Res. 47: 83-88.

Venugopalan, M.V., Sankarnarayanan, K., Blaise, D., Nalayini, P., Praharaj, C.S. and Gangaih, B. 2009. $B t$ Cotton in India and its agronomic requirements - A review. Indian J. Agron. 54: 343-60. 